\section{Education and Political Theory: Prospects and Points of View}

\author{
Rille Raaper ${ }^{1}$ and Mark Olssen ${ }^{2}$ \\ ${ }^{1}$ School of Education, Durham University, \\ Durham, UK \\ ${ }^{2}$ Department of Politics, University of Surrey, \\ Guildford, UK
}

\section{Synonyms}

Political theory; democracy; power; inequality

\section{Introduction}

Education, philosophy, and politics can be seen as the tripos in Western tradition, defining the canon and practices of political and educational institutions (Peters 2012). In the light of recent educational research, it could also be argued that the relationship between politics and education is gaining particular popularity. Various international journals such as Discourse: Studies in the Cultural Politics of Education, Journal of Education Policy, and Critical Studies in Education confirm these trends in scholarly discussions. Furthermore, many critical theorists see themselves grounded in Paulo Freire's (1921-1997) work on the political nature of education, particularly made visible in his collection The Politics of Education: Culture, Power and Liberation (1985).
However, the field of politics of education is highly diverse, often depending on a theoretical approach taken. Some go back to Plato, Aristotle, and Ancient Greek philosophies or find guidance from Enlightenment theories and the work of such scholars as John Locke (1632-1704), JeanJacques Rousseau (1712-1788), or Immanuel Kant (1724-1804). Others might focus on more recent economic theories of Marxism, human capital theory, meritocracy, or philosophical movements of post-structuralism and postmodernism. The theories of Michel Foucault (1926-1984) and Pierre Bourdieu (1930-2002) are particularly widespread in contemporary perspectives on political nature of education. However, the differences in political research are not only limited to theoretical approaches taken, but they vary depending on the questions asked. Some educational studies explore macro-politics of education: educational politics and policy making at global and national levels. These studies tend to be interested in the ways in which political decisions and strategies are developed and how these could be improved. However, Simons et al. (2009a) also argue that educational research is increasingly shifting from macro questions related to economic and organizational theories to critical policy studies in which the focus turns to micro-politics of education inside and outside educational institutions. These researchers distance themselves from the kind of educational research that was aiming to improve existing policy mechanisms, and they rather examine policies and politics in relation to 
social context, power, and experiences (Simons et al. 2009a). In short, critical studies have brought educational research closer to micropolitics in which the political concepts of power, autonomy, freedom, and resistance receive increasing attention.

The key focus in studies on micro-politics of education lies on the question of democracy and educational formation of citizens. These studies are concern oriented and often confrontational to policies and politics that actively aim to reorganize schooling and education based on the market and managerialist practices (Simons et al. 2009a). Dating back to the end of 1970s and bound with the development of the critical orientation to education policy, studies on micro-politics of education tend to be driven by societal challenges such as globalization, managerialism, and neoliberalism (Simons et al. 2009b). Our own political research has explored these challenges and argued that the processes of neoliberalization and globalization are particularly evident in higher education contexts with the consequent de-professionalization of academic work, standardization of academic practices, and the marketization of higher education (see Olssen and Peters 2005; Raaper 2015; Raaper and Olssen 2015). It could therefore be argued that educational research on micro-politics is not directed in the first place toward policy but toward the purposes and operation of education and schooling. Scholars inspired by critical policy studies believe that education fulfills a fundamental role in ensuring democracy and democratic formation of citizens. From this perspective, it is not policy or state government that can "save" the society, but it is education that offers an opportunity for emancipation from oppressive policy mechanisms. Furthermore, most studies on micro-politics of education can be regarded as democratic acts in themselves; they are committed to education and society as vividly explained by Simons et al. (2009a, 31):

The critical ethos is not in opposition to democracy, but is perhaps a way of living a democratic life, and a way to be concerned with or to be part of "the public and its education."
It could therefore be argued that the relationship between education and political theory is complex, and it varies across different dimensions: from macro-politics to micro-politics, as well as from ancient philosophies to contemporary theories of post-structuralism and postmodernism. These dimensions, however, cover a wide range of topics, theories, and theorists. This entry aims to map and introduce some of these political theories that are informing as well as transforming educational research. Furthermore, the entry guides the reader of this encyclopedia in exploring the relationship between education and political theory. We demonstrate the ways in which theories have informed recent scholarly work in education and our understanding of political concepts such as power, autonomy, identity, and resistance. The rest of this entry outlines a selection of entries included in this encyclopedia, creating an excellent starting point for anyone interested in educational research and political theory.

\section{Theoretical Insights: From Ancient Theories to Postmodernism}

The entry " $\triangleright$ Mapping the Terrain of Political Theory in Education" by Jeff Stickney demonstrates the complex nature of political theory in education and its historic development from Plato's Republic (1991) and Ancient Greek philosophies to Enlightenment theories of John Locke, Jean-Jacques Rousseau, and Immanuel Kant, as well as to more recent work of political theorists such as Paulo Freire, Michel Foucault, and Pierre Bourdieu. However, Stickney does not promote a linear understanding of political theories in which one theory transforms into another - a progress from "combat to combat" toward universal reciprocity as Foucault $(1977,151)$ would critique it - but he relates these theories to various schools of thought such as founding theories, liberal analytic philosophy, and Hegelianism. Stickney also emphasizes the more recent political work in education, particularly the contribution of critical theorists such as Henry Giroux, Michael Apple, and Peter McLaren. We admit that our selection of entries below is not sufficient to cover the 
extensive map created by Stickney; however, the theories of social liberalism, meritocracy, and human capital as well as postmodernist and feminist approaches aim to provide some food for thought to anyone interested in exploring the political nature of education.

The entry " $>$ T. H. Green, Public Education, and the Idea of Positive Freedom" by William Mace explores social liberalism in education and introduces the work of British idealist Thomas Hill Green (1836-1882). Green's contribution to public education and the idea of positive freedom cannot be underestimated. Inspired by Green's work, Mace explores the ways in which Green was influenced by earlier political thoughts of Ancient Greek philosophy as well as by the eighteenth century German idealists Georg Wilhelm Friedrich Hegel and Immanuel Kant. The entry highlights Green's response to the Industrial Revolution in nineteenth century and his understanding of education as a common good that requires state intervention and funding. Mace concludes by emphasizing the value of Green's theory to contemporary understanding of education: education is central for good life, "and [this idea is] especially pertinent today, where rapid technological advances, transnational economic markets, and international terrorism, are again challenging traditional conceptions of freedom and opportunity".

The entry " $>$ Meritocracy" by Ansgar Allen explores the legacy of Michael Young's dystopian essay "The Rise of the Meritocracy" (1958). Allen critically reviews the essay and highlights its relevance to contemporary educational debates. The entry argues that meritocracy is highly fluid and context-specific concept that depends on wider technologies of government. Allen argues that meritocracy as we experience it today is highly neoliberalized: it operates based on individual effort rather than on institutional intervention or social engineering proposed by Young (1958). Meritocracy for Allen is therefore "a descriptive term, and as an educational ideal, meritocracy exhibits remarkable, perhaps dangerous fluidity".

Like Allen's analysis on meritocracy, the entry " Human Capital Theory in Education" by Donald Gillies questions the societal value of education. Gillies explores the work of Theodore
Schultz (1902-1998) and Gary Becker (1930-2014) and argues that the human capital theory has transformed the ways in which we understand education: education has turned into an investment that is believed to produce individual value as well as to increase the quality of economic workforce. Gillies brings examples from the Organization for Economic Cooperation and Development and the European Union policy developments and argues that "Human Capital Theory has become one of the most powerful underpinnings of education policy discourses worldwide". The entry critiques this narrow understanding of education and the impact it has on schools, learners, and teachers. Gillies also questions the economic significance of the theory and argues that human capital theory does not produce clear economic value to justify its popularity.

Shifting toward postmodernist theories, the entry " $\triangleright$ Foucault, Confession, and Education" by Andreas Fejes explores the work of Michel Foucault (1926-1984) in relation to contemporary confession culture in education. Fejes provides a genealogical overview of confessional practices from Ancient Greek culture to Medieval Europe and modern societies. Contextualized in the past, Fejes argues that confessional practices today are understood as productive forces necessary for ensuring productivity of education, learning, and societies. More specifically, confessional practices (as these become evident from various assessment technologies) make "the innermost thoughts of the learner available for correction". Guided by a Foucauldian theorization, Fejes critiques that confessional practices in education allow subjectification and normalization of students: they create specific types of subjects who can be corrected and normalized. Fejes encourages educational researchers and practitioners to explore these often hidden confessional practices in education.

\section{Putting Theory into Practice: Examples of Educational Research}

The selection of entries below aims to demonstrate the ways in which particular theories can 
inform educational research and our theorization of political concepts such as educational leadership, inequality, citizenship, inclusion, and autonomy. The entry "> Feminist Theories and Gender Inequalities: Headteachers, Staff, and Children" by Kay Fuller explores feminist theories in relation to gender inequalities and school leadership. Fuller introduces the four historic waves of feminist theories: from suffragette movement in nineteenth century to the fourth wave located in twenty-first-century political concerns of sex work, transgenderism, and social media. However, Fuller also argues that each wave has something to offer to contemporary understanding of gender inequalities. Fuller explains her view by introducing the research project on headteachers' understandings of diversity among school populations in the UK. By drawing on the examples of headteachers Isabella and Katherine, Fuller argues that a single feminist theory is insufficient to explain the contemporary "nuances and complexities of gender as it is socially constructed".

Dina Kiwan theorizes the concept of "citizenship" in the entry " $\triangleright$ Citizenship, Inclusion, and Education." Guided by a wide range of political theories, Kiwan argues that "the concept of citizenship is a highly contested one; one which has been contested throughout its intellectual history." Like many other authors in the field, Kiwan goes back to Ancient Greek philosophy and explains the ways in which the early Greeks understood citizenship as a relationship between a person and the city-state or "polis." Kiwan also traces the understanding of the concept in feudal Europe and in the work of Thomas Hobbes, Jean-Jacques Rousseau, and John Locke. The entry finishes by exploring contemporary challenges around inclusion and citizenship, particularly in educational settings. Kiwan argues that there are multiple understandings of citizenship that draw on various educational approaches: "moral," "legal," "participatory," and "identity-based" conceptions of citizenship. However, the entry also notes that Western liberal democracies tend to rely on participatory transformative pedagogies when promoting inclusion.
The entry " $>$ Universities and the Politics of Autonomy" by Mark Murphy explores more recent issues of academic freedom, academic identity, and institutional democracy in higher education settings. Murphy draws on critical theory and explains that "political debates concerning the university are numerous and usually rancorous". The entry argues that highly popular Foucauldian and Marxist theories in university studies might not be sufficient to portray an adequate picture of contemporary university politics and processes. Murphy argues that the scholarly debate requires a more nuanced account of institutional autonomy in which the question of how do universities balance the competing demands for autonomy and control becomes the key focus of the critique and discussion.

Cristina Costa and Mark Murphy continue with the focus on university practices in the entry " $>$ Digital Scholarship and the Struggle for Academic Recognition." Costa and Murphy apply Pierre Bourdieu's (1930-2002) theory of practice and Axel Honneth's (born 1949) work on recognition and identity to explore the implications digital practices have on academic profession. The authors theorize the web as "a new alternative space where intellectual work can be discussed, published and made openly available to a wide range of communities". The authors demonstrate the ways in which two theoretical perspectives can complement each other when theorizing digital scholarship and the struggle for recognition. By using the work of Bourdieu and Honneth, the authors argue that changing academic identities should be seen within an intersection of different forms of power and recognition that relate to structural transformations as well as to emotionally charged workplaces.

\section{Conclusion}

As the work of various academics demonstrates, the relationship between education and political theory is widespread and complex. Educational researchers and practitioners can be guided by a variety of theories and theorists when exploring a wide range of educational topics and issues. One 
thing is certain, the use of political theory in education is gaining increasing popularity and scholarly attention. This is possibly because political theories allow us to question the role of education in wider society, particularly when the society is facing major material crises such as population growth, climate change, nuclear, and other forms of terrorism, economic recession along with more recent refugee crisis, and mass migration from developing countries. Therefore, the political issues in education such as power, the purposes of education, citizenship and inclusion, and educational and gender inequalities among many other concerns require increasing scholarly attention. We hope that the overview above provides guidance and food for thought to anyone interested in exploring the political nature of education.

\section{Cross-References}

$\checkmark$ Citizenship, Inclusion, and Education

- Digital Scholarship: Recognizing New Practices in Academia

- Feminist Theories and Gender Inequalities: Headteachers, Staff, and Children

- Foucault, Confession, and Education

- Green, Public Education, and the Idea of Positive Freedom

- Human Capital Theory in Education

- Mapping the Terrain of Political Theory in Education

- Meritocracy

- Universities and the Politics of Autonomy

\section{References}

Foucault, M. (1977). Nietzsche, genealogy, history. In D. F. Bouchard (Ed.), Language, counter-memory, practice: Selected essays and interviews (pp. 139-164). Ithaca: Cornell University Press.

Freire, P. (1985). The politics of education: Culture, power and liberation. Westport: Bergin \& Garvey Publishers.

Olssen, M., \& Peters, M. A. (2005). Neoliberalism, higher education and the knowledge economy: From the free market to knowledge capitalism. Journal of Education Policy, 20(3), 313-345.

Peters, M. A. (2012). Education, philosophy and politics: The selected works of Michael A. Peters. Oxon: Routledge.

Plato. (1991). The republic of Plato. (trans: Bloom, A.). New York: Basic Books.

Raaper, R. (2015). Academic perceptions of higher education assessment processes in neoliberal academia. Critical Studies in Education. doi:10.1080/ 17508487.2015.1019901.

Raaper, R., \& Olssen, M. (2015). Mark Olssen on neoliberalisation of higher education and academic lives - An interview. Policy Futures in Education, 14(2), 147-163.

Simons, M., Olssen, M., \& Peters, M. A. (2009a). Re-reading education policies. Part 1: The critical education policy orientation. In M. Simons, M. Olssen, \& M. A. Peters (Eds.), Re-reading education policy. $A$ handbook studying the policy agenda of the 21st Century (pp. 1-35). Rotterdam: Sense Publishers.

Simons, M., Olssen, M., \& Peters, M. A. (2009b). Re-reading education policies. Part 2: Challenges, horizons, approaches, tools, styles. In M. Simons, M. Olssen, \& M. A. Peters (Eds.), Re-reading education policy. A handbook studying the policy agenda of the 21st Century (pp. 36-95). Rotterdam: Sense Publishers.

Young, M. (1958). The Rise of the Meritocracy 1870-2033: An essay on education and society. London: Thames and Hudson. 